\title{
The Importance of Plan Unit Design with Reference to Pedentive Dome Mosque Architecture in Early Ottoman Period in Balkan Region and Anatolia
}

\author{
Ahmad Sanusi Hassan \& Mehrdad Mazloomi \\ School of Housing, Building and Planning, Universiti Sains Malaysia \\ 11800 USM, Penang, Malaysia \\ E-mail: sanusi@usm.my,mehrdad.mazloomi@gmail.com
}

\begin{abstract}
This study analyses development of pedentive dome plan unit design in Ottoman mosques built from $13^{\text {th }}$ to $15^{\text {th }}$ centuries (Early Ottoman Period). An expansion of new territories ruled under Ottoman Empire in Eastern Europe (Balkan Region) and Anatolia yields an influence of Turkish mosque style to the regional architecture. The Ottoman rulers had granted construction of many new mosques to cope with increasing number of the Muslim population. There are many studies about Ottoman mosque architecture done before but these studies fall short in terms of studying the development in plan unit design and its influence to the form of the mosques as a whole. This research aims to study evolution of the plan design to the extent to which it affects the plan layout. The study applies qualitative method of analysis. The survey has conducted over 51 mosques in this region, and it analyses possible variations of the evolution to the plan designs which are derived from pedentive dome mosque style. The study finds that there are six categories of the plan designs which are single dome plan, earring dome plan, multiple dome plan, duplication dome plan, courtyard dome plan and earring-courtyard dome plan. Primary domes, secondary domes and semi-domes are identified as the factors which influence variations of the plan units. Pedentive dome mosque architecture in this period is derived from six plan designs which typify development of the mosque architecture in Ottoman Empire.
\end{abstract}

Keywords: Early Ottoman, Pedentive dome, Plan unit design, Mosque

\section{Introduction}

This study discusses development of mosque architecture in Balkan region with reference to pedentive dome design and its effects to the plan layout. The method of this study applies classification of plan design using pedentive dome as main criteria to categorise the plan layout's variations of the Ottoman mosque architecture. The keywords are Early Ottoman, pedentive dome, plan unit design and mosque. Establishment of new territories and expansions under the Ottoman Empire from $13^{\text {th }}$ to $15^{\text {th }}$ century yielded to development of pedentive dome mosque architecture also known as Turkish or Ottoman mosque architecture. Crane (1993) noted that $13^{\text {th }}$ to $15^{\text {th }}$ century is the period of extensive building construction taken place in Ottoman territory to comply with an increase of the Muslim population especially construction of Jami Mosques as argued by Pasic (2004) as the existence of Muslim community in this region. The mosques are known as Cami in Turkish language, which mean mosques for congregational Friday's prayer. These mosque constructions had granted the Ottoman's master builders to enrich vocabulary and the design inspiration of the mosque architecture in the later periods (Crane, 1993 and Saoud, 2004). An increased number of mosques constructed resembles economic flourish (Flon et. al, 1984) throughout the towns and cities in parallel with the expansion of the Ottoman territory in Asia Minor (Anatolia) and South Eastern Europe (Balkan region). One can still find the prints today even though there is no more the existence of the Ottoman government. Pasic (2004) noted pedentive dome commemorates the foot print of the Ottoman architectural influence and Islam in South Eastern Europe.

Mosque design in this region applies 'pedentive dome' construction. Pedentive dome means a construction of 'dome above dome' technique or in other words a dome as if it is 'hanging in the air' over four giant arched supports (Mango, 1976). The unique of this type of dome construction is that it creates large multivolume space to the mosque interior. The construction uses load bearing technique. The dome has no structural system, therefore; it bears its own weight. The design minimises the usage of masonry construction materials (stones, bricks and marbles). Hagia Sophia (Figure 1) built in 537 AD highlights grandeur of the pedentive dome construction during Byzantium period. The upper dome has about 30.5 metre in diameter (Mango, 1976) 
supported by four grand arches which also bear a support for its four attached half dome. The support from these four giant arched columns however is insufficient. Additional pier buttresses are designed to give extra thrusts to the 'tension load'. Adoption of dome above dome concept had made possible for a design of large mosque interior space with 'multiple volume' in height. It is an ingenious work of Ottoman master builders by reinventing the pedentive dome concept of Hagia Sophia's architecture translated to the mosque design (Gulru, 2005). With a large interior space, excellent day lighting impact and dome stood at twice in height, it also reflects its architectural grandeur.

Many studies on the Ottoman mosques were conducted before by several scholars like Frederich Sarre, Albert Gabriel, Kurt Erdmann, Oktay Aslanapa, Aptullah Kuran and Metin Sozen (Crane, 1993). This study specifically refers to the mosque types and their typology compiled by Aptullah Kuran (1968). He classified the types of Ottoman mosques into three categories namely single-unit mosque, eyvan (iwan) mosque and multi-unit mosque design. He concluded that single unit mosque type has a prayer hall surmounted by a single dome whereas the eyvan mosque type is a mosque with interior space divided by several compartments of flat, vault or dome roof covers, and multi-unit mosque type has interior space with a series of dome roof covers. He specified the use of 'unit' instead of 'dome' by justifying the fact that the 'dome' hardly refers to its whole design context in contrast to the 'unit' which denotes the whole structural and spatial system. This demonstrates that he was aware of terminology of 'single dome' and 'multi dome'. For this reason, he categorised the mosque forms and their typology with single-unit and multi-unit mosque types. He denoted that multi-unit mosque's type is a popular style in Ottoman architecture and its later development.

\section{Material and methods}

This study is to discuss further contribution to the knowledge about the design of pedentive dome mosque with reference to the plan layout. It applies qualitative research method as a tool to categorise the mosque plan layout's types and their categories. This method employs research analysis using recorded documents and materials as an important sources as argued by Marshall and Rossman (1999). It investigates the pedentive dome mosque based on analysis of the mosque plan designs and their typology. The study is narrowed down its scope to the existing mosques and excludes those of which have been altered to a mosque from a church or temple origin for the analysis. There are 51 pedentive dome mosques built between $13^{\text {th }}$ and $15^{\text {th }}$ centuries selected in this study. Their construction dates can be traced back to the establishment of Ottoman Empire in early thirteenth century until the late fifteenth century, which resembles the mosque design during the Ottoman's golden ages and glory in architecture. The reason for this selection is to obtain efficient analysis to identify the development of pedentive dome mosques and their typology, as noted by Guba and Lincoln (2005) to validate the root and forming idea of Ottoman architecture.

The data used in this study consists of plan layouts derived from a book titled 'The Mosque in Early Ottoman Architecture' by Aptullah Kuran (1968). This book records the inventory of plans, sections and photos about Turkish mosques built during Early Ottoman period. This study is to elicit an argument with reference from the data that the pedentive dome mosques in Early Ottoman period could be classified into six different categories.

\section{Methodology}

The study investigates a further comprehensive study of the plan design from a study conducted by Kuran (1968) who concluded in his study that the basic principle of early Ottoman mosque is simple round dome, and square plan (Pasic \& Siravo, 2004 and Unsal, 1973) but he did not done elaborate study in defining the divisions of the plan design. This study will use the principle, as argued by Kuran (1968), by grouping the existing pedentive dome mosques into several categories. The first factor is analysing plan division with three subdivisions which are simple, combined and additive courtyard plan unit types. It is the symbol of Ottoman mosque architecture incorporating simple and pure geometric shapes (Bernardini, 1987 and Pasic \& Siravo, 2004) with dotted circles (representing domes) and continuous square plan with dotted lines (representing walls, doors, windows and other openings) illustrated in the plan layouts which create variations of the plan unit design. Simple plan unit type denotes a simple geometry of the plan design such as square while complexed plan unit type is a combination of different geometric elements such as one or more large squares flanking by two or small squares that creating the plan unit layout. The additive courtyard plan unit type on the other hand, resembles additional courtyard space as a part of the plan design. The second factor is analysing the dome divisions with reference to the plan design which has four subdivisions which are main dome, secondary dome, tertiary (riwaq) dome and semi dome. Acknowledging the fact that dome is a spatial element and its effect is more obvious observed from the elevations and three dimensional views, however; it is in the scope of this study only to analyse the plan unit 
design with reference to its number and size as important measurement in categorising the types of the plan layouts.

For instance the master builder who built Sehzade mosque could simply design a complete single pedentive dome instead of two half domes in addition to the main pedentive dome but he did not design that way. The reason is the focus on style that otherwise can never lead to the development of the mosque design in redefining the form and space and stunning beauty of the existing design. In this sense, the dome factor deals with the number as well as its size in reckoning the importance of pedentive dome in Ottoman mosque design. The main dome, the largest and the most dominant pedentive dome of the mosque, normally covers the main prayer hall (sahn) or central space of the mosque. Secondary dome refers to small domes placed around the main dome, and the number can be more than one. Semi dome accounts for the half dome design attached to the main dome that it create a large area for the prayer hall without having additional columns (structural supports) in its interior building (Hoag, 1963). All the combinations will be traced through an analysis in all the plan designs.

\section{Analysis}

This study assumes that the study of pedentive dome mosque with reference to its plan design can provide better description to the understanding of its evolution. This study classifies the design into 6 categories as follows:

\subsection{Single dome plan}

Single dome plan is the origin and most basic type of pedentive dome mosque. The later development of the plan mosque design is derived from this category. Mosques of Orhan Gazi in Gebze (Figure 2), Turkey and Karadjoz Beg in Mostar, Bosnia Herzegovina are two good examples. The plan and dome design are characterised as follows:

\section{a). Plan design}

Single dome plan design has the simplest plan unit layout compared to the other five categories of the pedentive dome plan design. The plan design comprises two basic geometric elements which are a square and dome. In the plan layout, the square element is represented by the building wall lines with doors and windows which mark its confined space functioned as the prayer hall whereas the circle element is indicated by the dotted circle line which represents a void, multivolume space surmounted under pedentive dome as the roof cover. Most plan layouts have dotted triangle lines which refer to the squinched arches as the dome structural support. Dimension of the prayer hall can be rectangular in shape. In this case, the plan design is outlined with an addition of dotted semi-circle line which represents attached half dome or semi-dome roof covers. The number of half dome roof cover can be more than one depending on the number of half domes attached to the primary pedentive dome's structure. Many mosques have additional riwaq area like Karadjoz Beg Mosque in Mostar and Ferhadija Mosque in Sarajevo as a part of the plan layout.

\section{b). Dome}

Dome size is important in determining the size of the plan layout which specifies dimension of the main prayer hall as well as the mosque. The bigger the dome is, the larger is the size of its main prayer hall. The reason is that the dome of single plan unit design attributes to single pedentive dome roof cover built at the centre of the mosque. The most discrete characteristic of this single dome plan design is that it has a dominant pedentive dome roof. Its dome's load is carried by four giant arches in most cases built as a part of the wall perimeter. These arches are typically surmounted on the walls by squinches. The use of attached semi-dome plan unit provides additional area of the main prayer hall. One of the half dome areas occasionally functions as an entrance side into the mosque. One to four semi-domes are possibly attached to the main dome depending to the design by the master builders.

\subsection{Earring plan design}

Earring plan is the second category of the Ottoman mosque's plan unit design. Its design is derived from single dome plan. Hatuniye Mosque in Tokat, Turkey (Figure 3) is one of the good examples. The plan layout is with the following characters:

\section{a). Plan design}

This category has the same plan design as the single dome mosque but its difference is an addition of two small square-bay plan units as room extensions to the plan layout of the central/primary plan unit. From the plan view, these spaces give the feeling of a pendent's looking. The shape of this plan layout shows these two building additions to the main hall functioned as a separate compound space. This design emphasises on the role of secondary prayer halls (iwans) or additional rooms as an important element in plan unit layout in order to 
increase the size of the mosque. In case of Hatuniye Mosque, the plan layout illustrates that there are two hierarchical orders of square plan units in the design. One is the primary square plan unit while the other two are secondary square-bay plans with the size about a quarter of the primary square plan. There is possibly a design of riwaq in the plan layout. It is an open area covered by a series of small roof domes functioned as a porch for a foyer area (sometimes used as exterior prayer areas) which lead to the entrance door to the main prayer hall.

\section{b). Dome}

Dome size has the same importance as the plan unit's size which determines the size of main prayer hall. Compared to single dome plan unit design, the master builders had alternative approach by complying additional square-bay plan units into the design in order to enlarge the size of prayer hall. The number of domes in this category can be more than one and the number can be increased up to three. There are one primary dome and two secondary domes which make up the space for main and two secondary prayer halls or room compartments. The design reveals that the master builders who design this earring plan design had applied design technique with hierarchical order of the dome sizes in creating additional interior spaces without requiring to enlarge the primary dome size. The primary dome is the single largest dome which surmounts the main prayer hall while the other two secondary domes function as roof covers for the other two additional spaces. In the plan layout, the domes are illustrated by dotted circle lines indicating the pedentive dome as the roof cover. A design with half dome roof cover attached to the pedentive dome is another method applicable when the prayer hall is elongated for its additional spaces. The plan design may either have a porch or riwaq allocated for the mosque's entrance or stand alone without a porch's entrance. In a case of the former version, a series of arched columns (colonnades) is designed to support the domes which create a series of square porches.

\subsection{Multiple dome plan design}

The third category has two types of dome plan unit design. This category has a combination of single dome and earring plan design, with an addition to multiple numbers of primary and secondary domes in the plan layout. An example of this category is Murad Pasa Mosque (Figure 4) in Istanbul, Turkey.

\section{a). Plan layout}

This plan layout has a main prayer hall which is indicated by two primary square plan units underlined by two dotted circle lines as the dome roof covers. It has in addition two secondary prayer halls at both of its bays (side wings) as illustrated by two secondary square plan units at the right and left bays of the main prayer hall. Combination of two primary square-bay units creates a rectangular main prayer hall. The advantage of this combination is that it has no obstruction of column or arched column in the interior main prayer hall. The same plan design applies to the interior space of secondary prayer halls. The main difference of this twin dome plan layout is that the dimension of the prayer halls is rectangular rather than square in shape. By having this rectangular plan layout, the master builders at that time are able to enlarge the prayer halls double in size without having a risk to design a single dome longer in span in order to enlarge area of the prayer halls. The focus of the mosque's enlargement is on an addition of square plan units rather than increasing the dome's diameter. The design has multiple square plan units in order to have multiple in sizes of the main and secondary prayer halls. Riwaq is normally a part of the plan design layout in this mosque's category. It has the same design as riwaq's area in the single dome and earring plan design.

\section{b). Dome}

Dome size is not as important as its plan unit's number in this mosque design. This means that the master builders add the number of domes two times of those in earring plan design to gain twice the size of the main and secondary prayer halls. In this multiple dome plan design and as its name reveals, it consists of two primary domes which become roof covers of the main prayer halls. One of these primary domes located at the centre of the plan layout is designated as a central dome, which has normally its height projected several metres higher than the other dome known as front dome. This height's difference is important to illustrate an importance of the central dome as a landmark of the mosque. The size of the prayer halls is determined by the number of the domes multiplied in the design like double, triple and so on. The fact is that this multiplication technique turns to duplications of primary and secondary domes. As the other categories, attached half dome roofing technique may also apply in the design.

\subsection{Duplication dome plan design}

The appellation of the next development to the multi-dome plan design is duplication dome plan design as the fourth category. Ulcami Mosque in Bursa, Turkey (Figure 5) resembles the characteristics of this category that can be conceptualised as follows: 


\section{a). Plan layout}

The mosque plan dimension of duplication dome plan unit design is either square or rectangular depending on how many duplications of the square plan units are made. All plan units have the same size. In this plan layout, it is obvious to find that the plan design is more important than the dome design in specifying the size of main prayer hall. The plan layout is a result of a combination of square plan units. It likes a modular system, duplication the same plan units to compose dimension of the mosque. All modules are square plan units as illustrated either continuous or dotted lines referring to their places in the design composition. The dotted line means there is no wall built as the perimeter but it is instead continuous dome roof covers supported by arched columns and vice versa. Locations of these arched columns are clearly shown in the plan layout. Each arched column has a cross shape as illustrated in the plan layout. The cross shape means that each column is located at four angles of intersection. Each bears and shares the loads of four pedentive domes. Riwaq's design is not very popular in this category but it can be traced in some cases as a part of the plan layout in several mosques such as Eski Cami and Zincirlikuyu Mosque (Kuran, 1968). Half plan unit with half dome module may be applied as additional dome roofing method in the design.

\section{b). Dome}

Dome does not play crucial role in determining the size of prayer hall. All domes have the same dimension. The size is however influenced by how many duplication of square plan units are used in the plan design. The duplication is arrayed either in row or in column projection. There is no primary or secondary dome in this category. All domes have the same size. Several mosques have a central dome; for example Eski Cami mosque with a projected lantern structure on one of its dome; and Ulucami mosque with an open copula at its central dome to illustrate its landmark. The master builders did not focus to increase the dome's diameter to enlarge the size of its primary plan unit but they rather applied duplication technique by combining all the plan units to determine the mosque's dimension. In contrast to main prayer hall of the other categories, main prayer hall of duplication dome plan design has repetitive columns inside its interior space. An original idea of pedentive dome design to acquire vast interior space without obstruction of arched column structures is not applied in this design. The design adopts a typical Arab mosque architecture as argued by (Hoag, 1963) which has an emphasis on duplication of plan units' design arched column structures inside the prayer hall.

\subsection{Courtyard dome plan design}

Courtyard plan design is the fifth category of the pedentive dome mosque. One of the good examples is Mosque of Guzelce Hassan Bey in Hayrabolu, Turkey (Figure 6). The characters of plan layout and dome are as follows:

\section{a). Plan layout}

The plan design shows that number of square plan units is used to determine the size of prayer halls rather than the dome size. It has similar layout to those in earring and multiple dome plan design. It has basically hierarchical order of two types of the plan units. The primary unit has a square plan unit with a large dome roof cover, which specifies a dimension of the main prayer hall. This plan unit is denoted by a square plan unit with continuous (wall) and dotted lines (indicating an open wall system), and dotted circle line (indicating the dome as a roof cover). Several secondary plan units are also integrated in the plan layout as an aisle part of the main prayer area. In case of Guzelce Hassan Bey mosque, its secondary plan units have a size a quarter of primary plan unit. By having two secondary plan units at the left and right bay (4 units together), the mosque has a total enlargement twice of its primary plan unit's size.

Figure 6 besides illustrates a plan layout with hard surface courtyard plan design (known as sahn) as a part of the mosque compound. This application is based on an influence by atypical Arab mosque architecture and the origin of the mosque in Quba' and Madinah built by Prophet Muhammad (Omer, 2008 and Syed Ariffin, 2005). The courtyard has a perimeter by corridors (riwaqs) supported by a series of colonnades. These corridors have either dome with arched column system or flat roof type, or a combination both of the roof types. The plan layout has normally a rectangular plan layout with respect to the fact that the spatial design of the prayer hall is the result from a combination of square plan units. The distinct character of this category is its discernable courtyard being added as a part of the plan layout. The plan layout illustrates that there are two types of the prayer spaces which are interior prayer hall and exterior (courtyard) prayer area. This courtyard area is used as an additional prayer area to tackle overcrowding normally when congregational Friday prayer takes place.

\section{b). Dome}

Dome does not play a significant role in specifying the dimension of the mosque's interior space. The master builders simply accounted on several numbers of primary and secondary plan unit modules with dome roof cover 
to the design to determine a total size of the prayer halls. Primary plan unit is designed at the centre functioned as the main prayer hall whereas its secondary plan units with small dome roof cover (a quarter in size compared to the primary dome size) are integrated in the design to create the additional spaces. Diameter of the dome does not significantly become an influential factor decided by the master builders in the design to obtain the size of prayer hall. The reason is that the use of several numbers of secondary domes in the design becomes an alternative solution to enlarge the area of prayer hall. The dome size becomes further less in its importance in specifying an area of the prayer hall with an application of exterior courtyard as additional prayer area in the design. The idea of courtyard as additional prayer area is brilliant, and more efficient in tackling the problem of insufficient space to the presence of a large number of Muslims to perform Friday prayer, which only lasts in one hour's time in a week. The interior main prayer hall functions as a place for daily congregational prayers where the numbers of people who perform these prayers are relatively small compared to those in Friday prayer.

\subsection{Earring dome courtyard plan}

Earring courtyard plan design is the sixth category of the pedentive dome mosque. It is the most complexed pedentive dome design during early period in Ottoman architecture. The design has an influence from earring and multi-dome plan design with exterior courtyard area. One of the best examples is the Mosque of Sultan Bayezid located in Edirne, Turkey (Figure 7). The characters of the mosque design are as follows:

\section{a). Plan layout}

The plan layout shows that applying modular plan unit system is very important in the design which accounts size of the mosque. The mosque interior area consists of main prayer hall, secondary prayer halls and rooms. There are two types of the plan units which are large and small plan units. A large plan unit covers a main prayer hall with a size limited to the length of dome's diameter as a roof cover. Additional bays of prayer areas are composed by secondary square plan units. Some of the units are converted into rooms. The more is the numbers of the plan units used in the design, the larger is the area allocated for prayer halls and rooms in the plan layout. Like courtyard dome plan design, this earring dome courtyard plan design has a courtyard for additional prayer area in its plan layout. The courtyard has four riwaqs as its perimeter. Some courtyard designs have a pond at the centre, used for ablution purpose. Its plan design has interior prayer hall and exterior (courtyard) prayer area. This courtyard area is used as additional prayer area to alleviate overcrowding especially for congregational Friday prayer.

\section{b). Dome}

The design does not significantly apply the dome size in determining the size of the mosque's interior space. Dimension of its prayer hall is influenced by how many primary and secondary square plan units used in the design of its plan layout. Each unit has dome roof cover. In case of earring dome courtyard plan design, the primary plan unit is at the centre while its secondary plan units are at its bays. Combination of primary with secondary plan units creates additional spaces for prayer halls. These areas are surmounted by an array of domes. Secondary plan units have smaller dome roof covers than primary plan unit. By using several numbers of domes in the mosque design, the master builders were able to design the prayer halls according to the requested dimension to fit the number of people engaging congregational Friday prayer. In addition, the builders also integrated exterior courtyard prayer area as alternative solution to provide additional prayer areas. The use of courtyard in the design causes the role of dome design in specifying the dimension of prayer area (interior and exterior) becoming less importance.

\section{Discussion}

Pedentive dome mosque becomes a symbol of Ottoman architecture. This style is influenced by Byzantium architecture. One of the great buildings is Hagia Sophia, a symbol of Byzantium architecture. Evolution of the Ottoman mosques' plan layout however had evolved based on its own architectural style and identity by emphasizing the importance of plan unit design taken place from $13^{\text {th }}$ to $15^{\text {th }}$ century throughout the Ottoman Empire. This evolution is illustrated in a diagram in Figure 8. The development during this period marks the origin of Turkish architecture. The research findings denote the styles which are as follows:

\section{a). Plan layout with pedentive dome}

Pedentive dome is a crucial element in a plan design. The dome size influences dimension of the plan unit. The bigger the dome is, the larger is the dimension of the plan unit. The plan unit has a square shape because it's shape is influenced by the dome which covers the roof, a load bearing round dome roof type.

\section{b). Multiple volume pedentive domes construction}


Pedentive dome design is a basic construction in Ottoman as well as Byzantium architecture. The advantage is it creates vast interior space plan layout without obstruction by walls and columns with sunlit's penetration into the building (Goodwin, 1993). The idea is to transmit the daylight into the interior space from upper window openings at the projected primary and secondary domes that besides intensifying a sense of sacredness (Hillenbrand, 1994). The difference is that Ottoman mosques (except single dome plan design) have an emphasis on multiple domes in the design in contrast to single dome design of Hagia Sophia.

\section{c). Plan unit}

The design focuses on square plan units rather than its dome design to determine a dimension of the prayer hall in contrast to Hagia Sophia plan design specified by its dome size (the longer is the dome's diameter, the larger is the prayer hall's area). Saoud (2004) argued the plan design reveals that the master builder's works have an emphasis on variations of plan design with reference to composition of square plan units. The size of the mosque (as well as prayer hall) depends on the number of square plan units used in the design. The addition of square-bay's plan units has an influence from Arab mosque design as noted by Hoag (1963) by referring to Arab mosques like Umayyad Mosque in its neighbouring territory, Damascus and Aleppo in Syria. The dome's size is not as important as the number of plan units used in the design of Ottoman mosques. Only plan layout of single dome plan design's category verifies an importance of the dome size in specifying a dimension of the prayer hall.

\section{d). Dome size}

Dome's size (as illustrated by dotted circle lines) does not play as important role in contrast to the number of square plan units in the mosque design. The master builders had less focus on expanding a diameter of the pedentive dome (Unsal, 1973). They were instead mastering on composing a mosque with a combination of square plan units with dome roof cover used either multiple or duplication technique to determine the mosque size. By this design (unlike Hagia Sophia), there is no need to have massive pier supports (buttresses) or in case with large pedentive dome mosques like Suleimaniye or Sultan Ahmed Mosque in Istanbul and Banya Bashi Mosque in Sofia, Bulgaria; minimum pier supports are needed (Unsal, 1973 and Goodwin, 2005). During this period, the only available construction technique is based on load bearing wall construction. There is yet an existence of structural rib vault and dome as well as pointed arch, vault and dome construction. Round arch and dome therefore are the only construction elements at that time which are able to specify the building size in a long span construction concept. Compared to pointed dome, round dome has the same radius of its width and height. This means that when the width is constructed longer, its height should be constructed higher. There are therefore a risk and limitation in designing load bearing pedentive dome construction, and the Ottoman master builders prefer to avoid this risk and have more precaution on its safety.

\section{e). Hierarchical dome system in plan design}

As indicated in the plan layout, hierarchical order in a design of pedentive domes is popular in Ottoman mosque construction. Most mosques in this region have three types of the dome sizes which are primary, secondary and tertiary domes. Many mosques have only one primary dome but in some cases, there are mosques with more than one primary domes used in the design. Primary dome's plan unit covers an area of the main prayer hall. All mosques, except mosques with single dome's plan design, have secondary domes built with the primary dome (Saoud, 2004). The number of secondary domes used in the design is depending on the size needed for additional prayer spaces and rooms allocated for congregational Friday prayer. The other dome type is tertiary domes, which normally function as roof covers for corridor areas known as riwaqs.

\section{Conclusion}

Pedentive dome is an important element in a plan design of the Ottoman mosque architecture during $13^{\text {th }}$ to $15^{\text {th }}$ century. Pedentive dome is a construction of a dome above dome's construction system, which creates a vast interior and multiple volume spaces. The design emphasis is however not focussing to the dome (except single dome plan design) but it is to the number of square plan units to determine dimension of the prayer halls. The more is the number of square plan units used in a plan design, the larger is the size of prayer halls. Even though the dome size influences a size of square plan unit, its size does not play a significant role in specifying the size of plan layout. The master builders adopted hierarchical ordering system by integrating primary, secondary and tertiary (riwaqs) square plan unit modules in the design to specify dimension of the prayer halls and variation of the plan layouts. The latest design has an integration of courtyard functioned as exterior prayer area with riwaqs as its perimeters. All in all, this design concept leads to the development of pedentive dome mosque architecture in later period in the Ottoman Empire. 


\section{Acknowledgement}

The authors would like to thank to the Research Creative Management Office (RCMO), Universiti Sains Malaysia (USM) for the financial support for this research project.

\section{References}

Bernardini, M. (1987). The impact of Sinan on Turkish revivalism. Environmental Design: Journal of the Islamic Environmental Design Research Centre, A. Petruccioli (ed.), 1-2, 216-221.

Crane, H. (1993). Notes on Saldjuq architectural patronage in thirteen century Anatolia. Journal of the Economic and Social History of the Orient, 36(1), 1-57.

Flon, C., et. al. (1984). The World Atlas of Architecture (Le Grand Atlas de l'Architecture Mondiale). C. Dufton, et. al. (trans.). London: Mitchell Beazley International Ltd.

Guba, E.G. \& Lincoln, Y.S. (2005). Paradigmatic controversies, contradictions, and emerging influences. The Sage Handbook of Qualitative Research, N.K. Denzin \& Y.S Lincoln (eds.), $3^{\text {rd }}$ ed. Thousand Oaks, CA: Sage. 191-215.

Goodwin, G. (2003). A History of Ottoman Architecture. London: Thames \& Hudson Ltd.

Goodwin, G. (1993). Sinan Ottoman Architecture and its Values Today. London: Saqi Books.

Gulru, N. (2005). The age of Sinan: Architectural culture in the Ottoman Empire. Muqarnas: An Annual of Visual Culture of the Islamic World, N. Gulru (ed.), London: Reaktion Books, 24, 141-184.

Hillenbrand, R. (1994). Islamic Architecture: Form, Function and Meaning. Edinburgh: Edinburgh University Press.

Hoag, John D. (1963). Western Islamic Architecture. London: Prentice-Hall International.

Kuran, A. (1968). The Mosque in Early Ottoman Architecture. Chicago and London: The University of Chicago Press.

Mango, A.C. (1976). Byzantine Architecture. New York: Harry N. Abrams Inc.

Marshall, C. \& Rossman, G.B. (1999). Designing Qualitative Research. $3^{\text {rd }}$ ed. Thousand Oaks, CA: Sage.

Omer, S. (2008). The Origins and Functions of Islamic Domestic Courtyards. Kuala Lumpur: International Islamic University Malaysia Press.

Pasic, A. (2004). A short history of Mostar. Conservation and Revitalisation of Historic Mostar, Geneva: The Aga Khan Trust for Culture, 5-12.

Pasic, A. \& Siravo, F. (2004). Reclaiming Mostar's monuments and buildings. Conservation and Revitalisation of Historic Mostar, Geneva: The Aga Khan Trust for Culture, 47-56.

Saoud, R. (2004). Muslim Architecture under Ottoman Patronage (1326-1924). L. Ball (ed.). Manchester: FSTC Limited.

Syed Ariffin, S.I. (2005). Architectural Conservation in Islam: Case Study of the Prophet's Mosque. Skudai: Universiti Teknologi Malaysia Press.

Unsal, B. (1973). Turkish Islamic Architecture in Seljuk and Ottoman Times 1071-1923. London: Academy Editions. 


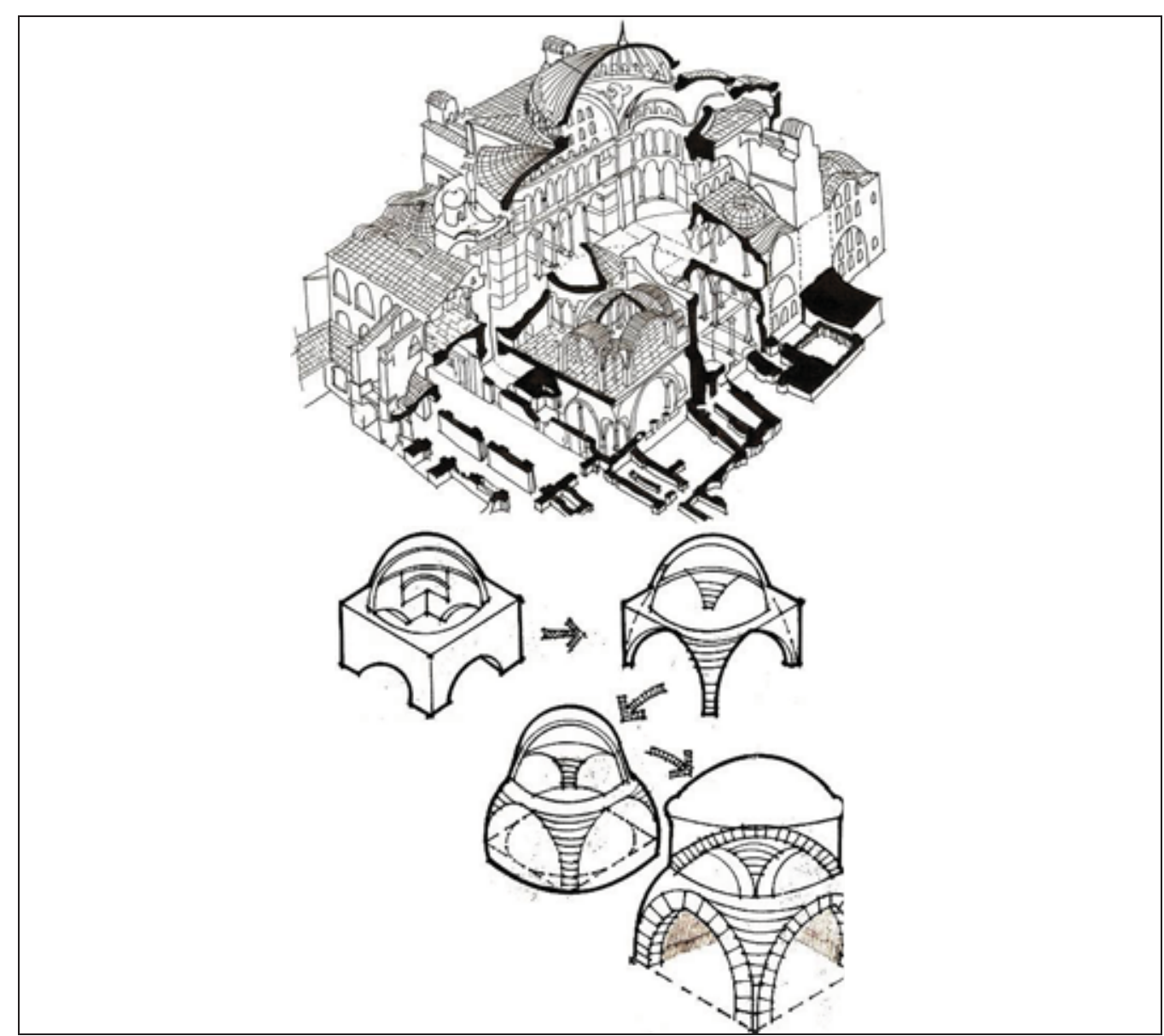

Figure 1. Pedentive dome construction, Hagia Sophia (left) and the types of pedentive dome construction (right) Sources: Drawn by Nurfasha Ahmad (student), Universiti Sains Malaysia

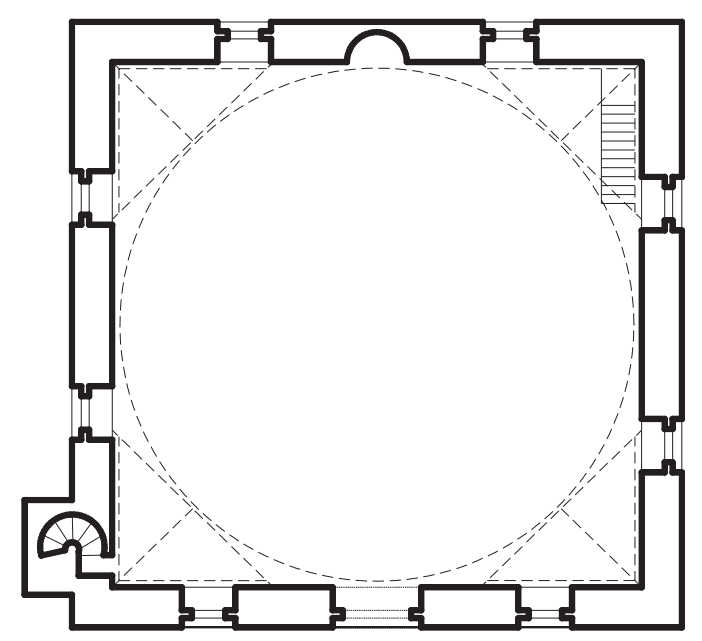

Figure 2. Mosque of Orhan Gazi

Source: Drawn by Mohamad Nazri Radzi (assistance researcher), Universiti Sains Malaysia 


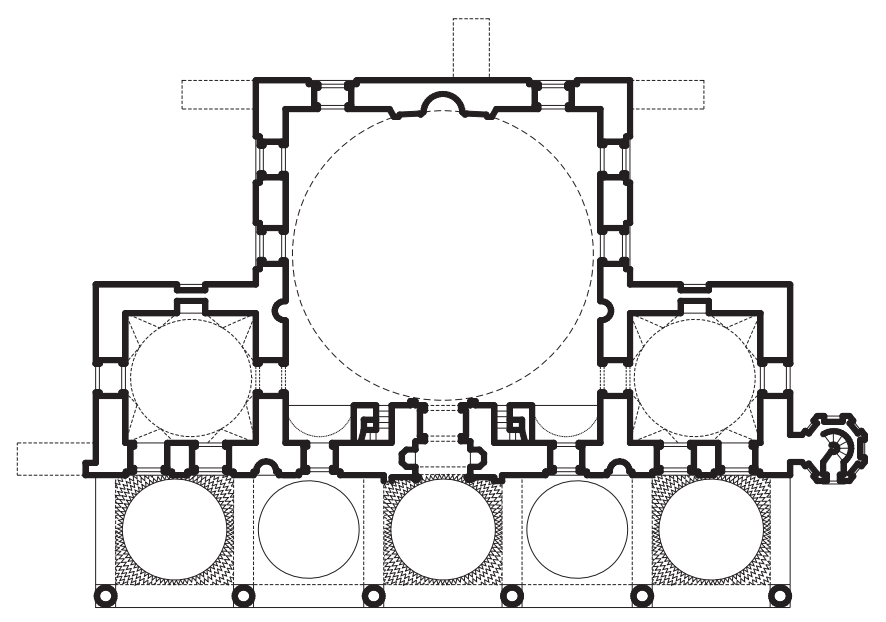

Figure 3. Hatuniye Mosque

Source: Drawn by Mohamad Nazri Radzi (assistance researcher), Universiti Sains Malaysia

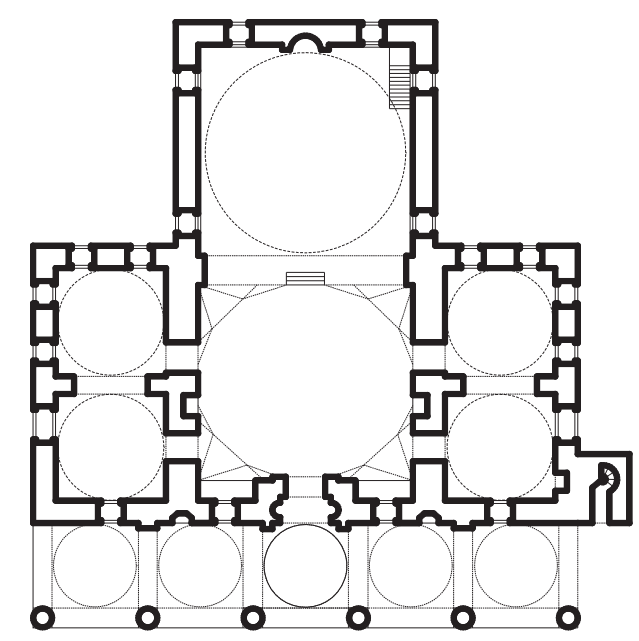

Figure 4. Murad Pasa Mosque

Source: Drawn by Mohamad Nazri Radzi (assistance researcher), Universiti Sains Malaysia

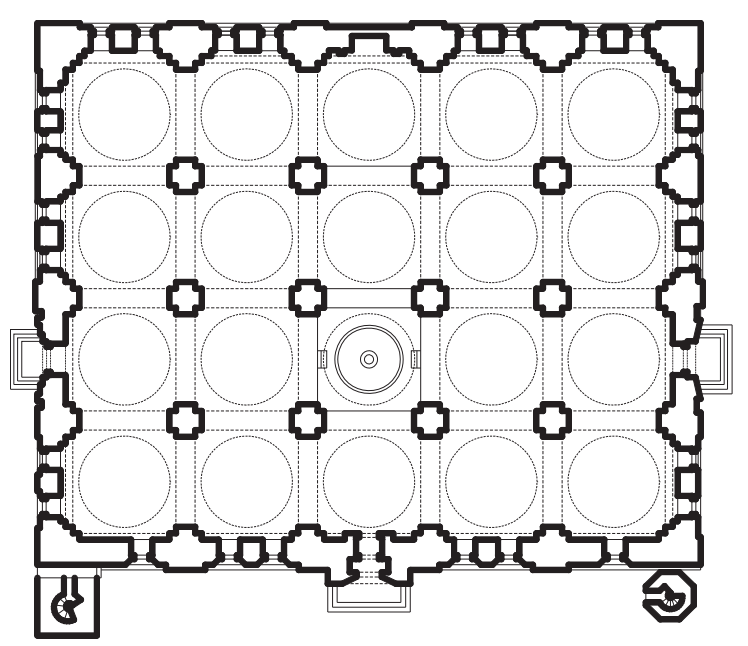

Figure 5. Ulucami Mosque

Source: Drawn by Mohamad Nazri Radzi (assistance researcher), Universiti Sains Malaysia 


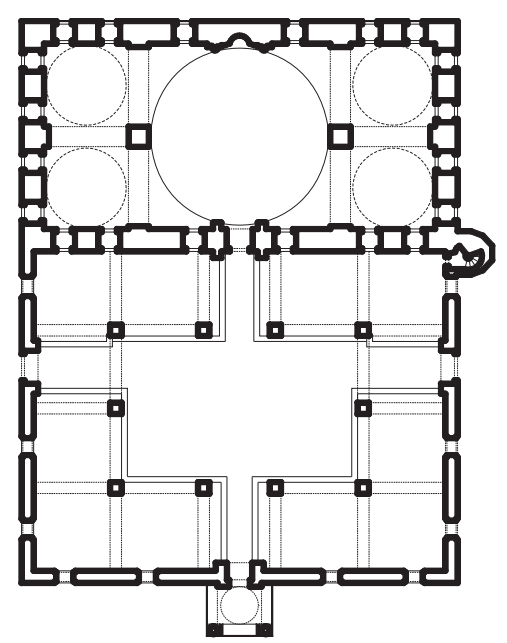

Figure 6. Guzelce Hassan Bey mosque

Source: Drawn by Mohamad Nazri Radzi (assistance researcher), Universiti Sains Malaysia

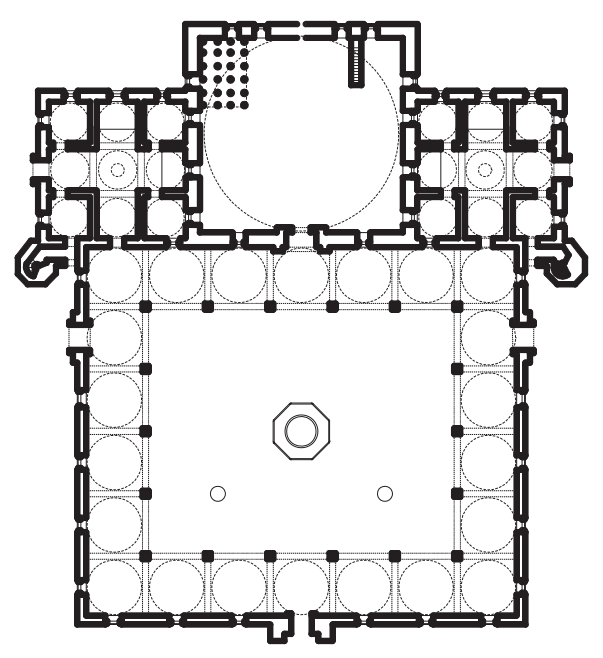

Figure 7. Mosque of Sultan Bayezid

Source: Drawn by Mohamad Nazri Radzi (assistance researcher), Universiti Sains Malaysia 


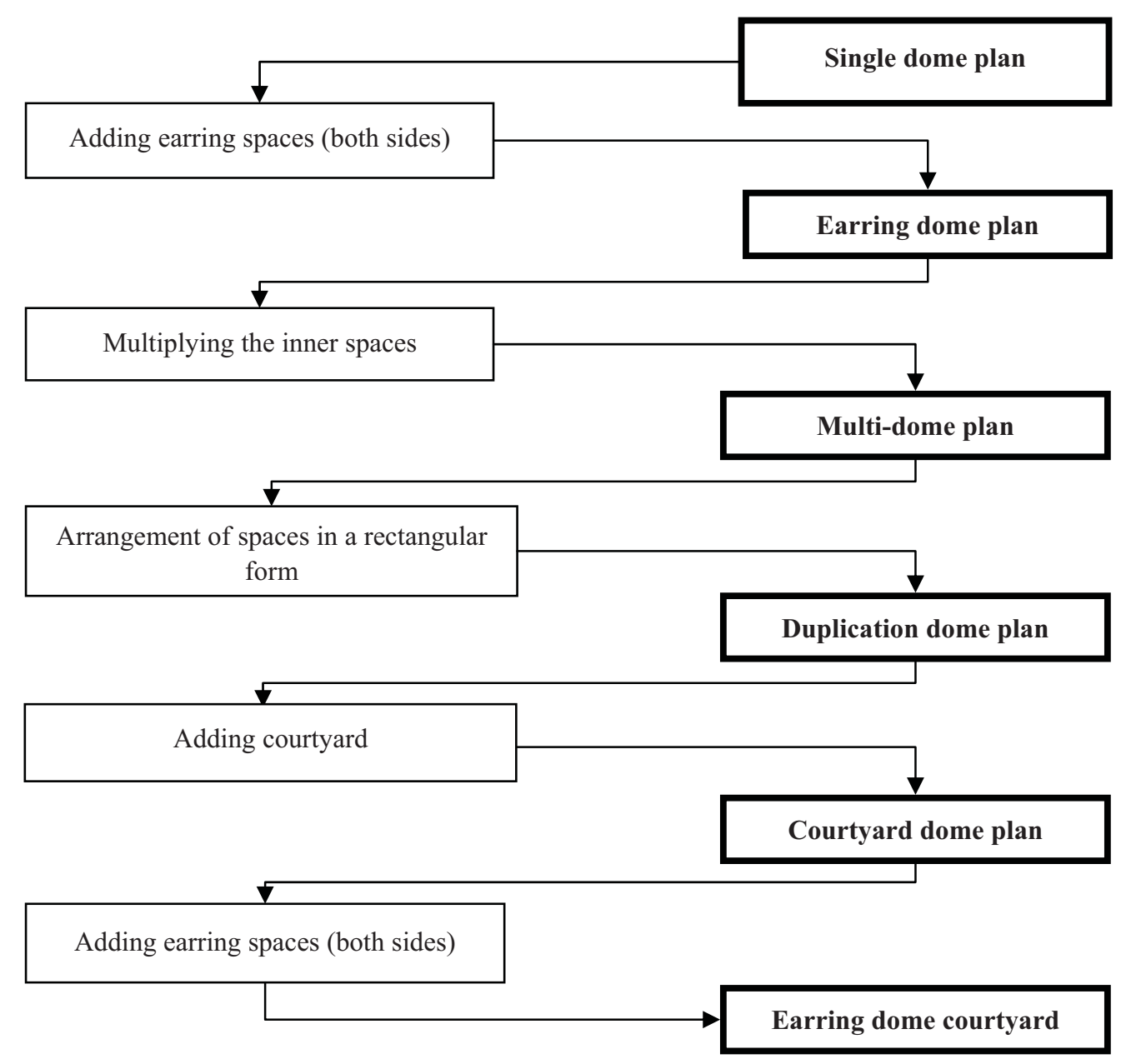

Figure 8. Evolution of Pedentive Dome Mosques in Early Ottoman Period 